\title{
What can medical ethics learn from history?
}

\author{
Kenneth Boyd Edinburgh University
}

Fifty years after the end of World War II, many still find it hard to understand how doctors were persuaded to become willing agents of Nazi ideology. What can medical ethics learn from the history of this dark time?

In one area the answer is clear. The Helsinki standards for biomedical research involving human subjects are evidence of determined agreement that nothing remotely like the Nazi 'medical experiments' should ever happen again. But another area remains disturbingly controversial. It has long been known that under the name of 'euthanasia', the Nazis systematically murdered up to 200,000 mentally ill and physically disabled children and adults; and those opposed to voluntary euthanasia have often cited this as a warning of what legalising it could lead to. But reliable historical evidence of what actually happened, and in particular of how doctors allowed themselves to be involved, was not available to English readers until the publication last year of Michael Burleigh's study: Death and Deliverance: Euthanasia in Germany 1900-1945 (1).

Burleigh's findings are both reassuring and disturbing. It is reassuring to learn that what made the Nazi 'euthanasia' programme first thinkable and then feasible, was not legislation permitting euthanasia. This was drafted by the Nazis, but never enacted, partly because they feared it would fuel enemy propaganda, but also because they realised that legal process would obstruct the murderous efficiency of their programme. In this respect, 'euthanasia' in Germany was very different indeed from what happens under the same name today in the Netherlands, where each step has been debated and monitored in the public arena and no relevant information, however damaging, is denied to potential critics.

Burleigh's more disturbing findings, indeed, may be less relevant to the Netherlands than to countries, such as Britain and the United States, in which euthanasia is not yet legal. He traces the pre-history of Nazi 'euthanasia' back to before World War I, when public sympathy began to emerge for the argument that people suffering from a terminal illness had 'a right to die'. But even at this early stage, this argument was regularly muddied by comparing the treatment of these patients with that of incurably sick animals. After the war, but before the Nazis came to power, the view that it would be 'kinder' painlessly to end the lives not only of the terminally ill, but also of mentally disabled children and adults, was increasingly articulated by ordinary people - who accepted the perceptions, on the one hand of cost-cutting governments that Germany could not afford to maintain its large population of long-stay asylum patients, and on the other of those academic doctors and lawyers whose crude eugenic theories represented these patients as 'life unworthy of life'.

\section{Troubling resonance}

Today, with genetics and economics again high on the health care agenda, these historical echoes have a troubling resonance. Seeking our faults, and hence their cure, not in ourselves but in our genes, remains a potent temptation to vain or underfunded scientists, to impatient patients or parents, and to a public fed by sensation-hungry media. Modern medical genetics, fortunately, is humbler, wiser and more practical than the crude eugenics of the 1920 s. But it is an open question whether the same can be said of political-economic projections which perceive care of the elderly as a burden the nation cannot afford and which now must be shouldered by the elderly themselves or by their families.

The disturbing thing here is not that history is about to repeat exactly what happened in the 1940s. No one steps into the same river twice. The risk today is not, that because society cannot afford ideal care for everyone, elderly people in general will be done away with as an insupportable burden. The risk, rather, is that if the care which wealthy societies like Britain and the United States can afford, is not distributed fairly, the less well-off elderly may be seen by their families or by themselves as such a burden. This at least seems to be the reasoning of those who argue that society's prohibition of intentional killing is necessary to safeguard such vulnerable people from 'pressure, whether real or 
imagined, to request early death' (2). Yet the very fact that this reasoning is required, is scarcely creditable to wealthy societies which claim to be civilized. If they want to substantiate that claim, history's lesson may be that a better-informed electorate, with whom politicians can be honest about the realities of economic choice, is urgently needed.

But to make a distinction between killing and letting die the crucial moral boundary which must not be crossed, is to beg the question not only of political but also of individual justice. In countries where voluntary euthanasia is illegal but where, were it legal, some doctors would be willing to assist the deaths of those patients with whom they judge it medically and morally right, some of those patients are being treated unjustly. The historical lesson here is the other side of Burleigh's warning about the animal-euthanasia kind of argument, which leaves the person's judgment of his or her own interests out of account. To paraphrase Caiaphas: it is expedient that some persons should not die yet, for the sake of the people.

But what, as Caiaphas might also have said, is the alternative? Arguably, there is a moral boundary, which, if it is not crossed, provides greater safeguards. This is to say that the step, which should never be taken down the 'slippery slope' that appears whenever euthanasia is in question, is one from judgments made with, to judgments made about, the person concerned - the step from judgments made in the first person (singular or plural), to judgments made in the third person.

A classical account of what is needed for this step not to be taken is found in what the philosopher Simone Weil wrote about 'attention', particularly to fellow human beings reduced by suffering (3). Helpful philosophical commentary on this 'unsentimental, detached, unselfish, objective attention' has also been provided by Iris Murdoch (4) and Dorothy Emmet (5), and most recently by the lawyer Joseph Vining, whose fine From Newton's Sleep, includes the following vignette (6).

\footnotetext{
'What does a person really want?

What does a person want?

"I want to die," a person says.

"No," comes the frequent response, "You don't. You are not being yourself."

This you is not an immediate phenomenon heard materially here and now. This you is an existence over time, with a past and a potential, whose voice you listen for continuously while making judgment after judgment whether to respect or discount the words you hear one after another.'
}

What Vining describes here, of course, is an ideal of the kind of conversation required for doctor and patient together to determine whether this is an occasion when allowing the patient to die, or (rarely, $m$ because there is often a better agreed alternative) $\overrightarrow{\bar{\sigma}}$. assisting his or her death, is morally appropriate. Such ideals, Dorothy Emmet argues, can play a vital $\overrightarrow{\vec{F}}$ role in orienting practice towards goals or standards $\stackrel{\oplus}{+}$ that can be approached even when they cannot be fully realised. Clearly there are occasions when it is $\frac{\bar{\sigma}}{\bar{N}}$ not possible to realise the ideal, the most difficult being those concerning neonates. But this in turn is $\stackrel{\Phi}{\triangle}$ why many doctors, nurses and parents with profound experience of such occasions acknowledge $\vec{\circ}$ that they are and always should be 'agonising' (7).

History's lesson from the Nazi era may be that $\vec{\omega}$ asking so much of doctors is asking too much of $\frac{\text { S }}{3}$ medical virtue. This may be the deepest reason why many doctors and others resist the legalisation of $\vec{\sim}$ voluntary euthanasia. But history is much longer $\vec{A}$ than the Nazi era, and our dismay over that era is a tribute to countless other doctors whose practice has $\vartheta$ been oriented by imperfectly realisable ideals. It is $ᄋ$ also worth noting Burleigh's observation that the doctors who collaborated with the Nazis received little or no education in medical ethics and some argued that 'everything was relative, including codes of medical ethics' (8). Medical education today is $\vec{\varphi}$ beginning to take teaching in ethics, communication of and practice skills more seriously. This cannof ensure that all future doctors, when patients. (whether or not voluntary euthanasia is legalise ask to be allowed or helped to die, will invariably respect the moral boundary between first and third person judgments. But it should help orient their practice towards that ideal; and that will be one small step in the direction of learning from history.

Kenneth Boyd teaches medical ethics at the University of Edinburgh, and is Research Director of the Institute of Medical Ethics and a member of the journal's Editorial Board.

\section{References}

(1) Burleigh M. Death and deliverance: 'euthanasia' in 윽 Germany 1900-1945. Cambridge: Cambridge $\frac{D}{8}$ University Press, 1994

(2) House of Lords. Report of the select committee on medical ethics. London: HMSO, 1994; I: 49.

(3) Weil S. (Translated by Craufurd E.) Waiting on God. N London: Routledge, 1951. (4) Murdoch I. The sovereignty of good. London: ${ }^{\omega}$
Routledge, 1970.

(5) Emmet D. The role of the unrealisable: a study in regulative ideals. London: Macmillan, 1994.

(6) Vining J. From Newton's sleep. Princeton, NJ: Princeton University Press, 1995: 181.

(7) McHaffie H. Holding on? Hale, Cheshire: Books for Midwives Press, 1994.

(8) See reference (1): 18. 